Research Report No. 55/2013

\title{
Lon Fuller's Political Jurisprudence of Freedom
}

Dan Priel

Osgoode Hall Law School of York University, dpriel@osgoode.yorku.ca

Follow this and additional works at: http://digitalcommons.osgoode.yorku.ca/clpe

\section{Recommended Citation}

Priel, Dan, "Lon Fuller's Political Jurisprudence of Freedom" (2013). Comparative Research in Law \& Political Economy. Research Paper No. 55/2013.

http://digitalcommons.osgoode.yorku.ca/clpe/297 


\section{OSGOODE}

OSGOODE HALL LAW SCHOOL

YOR K UNIVERSITY

\section{OSGOODE HALL LAW SCHOOL}

Comparative Research in Law \& Political Economy

RESEARCH PAPER SERIES

Research Paper No. 55/2013

Lon Fuller's Political Jurisprudence of Freedom

Dan Priel

Editors:

Peer Zumbansen (Osgoode Hall Law School, Toronto, Director Comparative Research in Law and Political Economy)

John W. Cioffi (University of California at Riverside)

Comparative Research in Law \& Political Economy 


\title{
Lon Fuller’s Political Jurisprudence of Freedom \\ Dan Priel
}

\begin{abstract}
Lon Fuller wrote extensively on freedom, but these writings are now largely unread. It is rare to find them mentioned, rarer still to see any attempt to relate their ideas to Fuller's writings on law and legal theory. Perhaps reflecting the widely-accepted dichotomy between jurisprudence (conceptual) and political theory (normative), these works are thought irrelevant to discussions on the nature of law. Fuller himself, however, never accepted this dichotomy, so in this essay I try to offer an alternative reading of Fuller's Morality of Law in light of his writings on freedom. I argue that Fuller's book should be understood as part of a broadly "republican" view of freedom, which sees both law and freedom as the opposite of tyranny. I argue that there is considerable textual support both in The Morality of Law and in his writings on freedom for a normative account of the nature of law, one that does not exist peacefully alongside (let alone presuppose) a conceptual inquiry, but rather challenges the possibility of value-neutral conceptual analysis of law.
\end{abstract}

\section{Introduction}

Some years ago Brian Leiter published an essay with the title "Is There an 'American' Jurisprudence?" As one comes to expect from titles like this, he answered with an emphatic "No." Jurisprudence is to law, he suggested, as the philosophy of science is to science; ${ }^{2}$ and just as it makes no sense to talk about American physics, one should not speak about American jurisprudence. Leiter is by no means alone; in fact, this view seems to be the prevalent one among contemporary legal philosophers. In the words of Joseph Raz, the mark of legal philosophy is that it is concerned with "the necessary and the universal" about law. What distinguishes legal philosophers from others writing on law, and what gives their abstract and seemingly pointless debates their raison d'être, is that they concerned to identify what law is, wherever and whenever it exists.

\footnotetext{
"Associate Professor, Osgoode Hall Law School, York University. An earlier version of this essay was presented in a symposium entitled "The Morality of Law at 50 " at the University of Oxford. I thank Denis Galligan and the audience for their comments and questions. I also thank Chris Boom, Eric Claeys, and Amir Paz-Fuchs, for very helpful written comments and suggestions.

${ }^{1}$ The essay is now reprinted in BRIAN LeITER, NATURALIZING JURISPRUDENCE: ESSAYS ON AMERICAN LEGAL REALISM AND NATURAlism IN Legal Philosophy 8 I - 102 (2007).

${ }^{2}$ See id. at 84; but cf. Dan Priel, The Scientific Model of Jurisprudence, in NeUTRality and THEORY Of LaW 239 (Jordi Ferrer Beltrán et al. eds., 2013) [hereinafter NEUTRALITY].

${ }^{3}$ Joseph Raz, The Authority of LaW: EsSAYS ON LAW AND MORAlity ro4 (2d ed. 2009); see also id. at 44; cf. Andrei Marmor, LAW IN THE AGE OF Pluralism i36-37 (2007) (distinguishing philosophers' interest "in truth" with intellectual historians interest in philosophers" "motivation" for their claims); H.L.A. Hart, Introduction to JOHN AUSTIN, The Province of Jurisprudence Determined, at vii, xv (H.L.A. Hart ed., i954) ("Analytical and historical inquiries provide answers to different questions not different answers to the same questions").
} 
This approach really came to dominate English-language jurisprudence in two famous works by H.L.A. Hart, both published a little over fifty years ago. ${ }^{4}$ In these works Hart redefined the domain of jurisprudence and established it, in line with prevalent philosophical ideas in the English-speaking world at the time (especially at Oxford), as a philosophical inquiry of the "nature" or "concept" of law. ${ }^{5}$ These works also happened to be part of the decade-long exchange between Hart and Lon Fuller that is now known as the "Hart-Fuller debate."

It is fair to say that among legal philosophers most now believe that, not to put a fine point on it, Hart wiped the floor with Fuller. In part, this is because Hart wrote in a style philosophers find more congenial. In part, I think, the reason is that The Morality of Law has been misunderstood. Due to the extraordinary influence the Hartian conceptual approach has had on English-language jurisprudence in the last fifty years, his approach has become dominant, so dominant in fact that many have come to think of it as the only way to approach the subject. As a result, Fuller's own work has usually been interpreted as an internal, conceptual, challenge to Hart's account of the nature of law, one that implicitly accepts the analogy between the philosophy of law and the philosophy of science.

I believe Fuller's work makes more sense understood not as a half-hearted attempt at conceptual jurisprudence, but as a committed effort at political jurisprudence, roughly, as an attempt to provide an account of the role of law in a political community given certain political commitments. In this essay I will try to show that by drawing on Fuller's largely forgotten writings on freedom and connecting the ideas found in them to his jurisprudential writings. After reconstructing Fuller's argument I will argue that his positions presuppose political ideas that have been prominent in American political history. In this respect The Morality of Law, like much else that Fuller has written, is properly understood as "American jurisprudence," not because it was written by an American, but because it was written against the background of the American political tradition.

Such a view is not immediately a challenge to conceptual jurisprudence. In fact, it would seem to show that Fuller was interested in very different questions from the ones Hart and other legal philosophers have been concerned with. It becomes a challenge to the very idea of conceptual jurisprudence if it is possible to show that it makes no sense to talk about the nature of law outside any such political foundations. That is how I will then argue one should read The Morality of Law. This may not immediately seem the most natural reading of the book, because much of what Fuller says looks as though he is trying to meet Hart on his own conceptual terms. There are, however, good reasons to think this is not how Fuller wanted to be understood. Though I will address the matter in

\footnotetext{
${ }^{4}$ H.L.A. Hart, The Concept of LaW (3d ed. 20 I 2) (196I) [hereinafter Hart, ConcePT]; H.L.A. Hart, Positivism and the Separation of Law and Morals, 7 I HARV. L. REV. 593 (1958) [hereinafter Hart, Positivism].

${ }^{5}$ See Dan Priel, H.L.A. Hart and the Invention of Legal Philosophy, 5 Problema $30 \mathrm{I}$ (201 I). The idea of general or universal jurisprudence predated Hart, of course, but it usually had meant something quite different. See id. at 306; Dan Priel, Two Models of General Jurisprudence, 4 TRANSNAT'L LEGAL THEORY (forthcoming 20I4), available at http://ssrn.com/abstract $=2295236$.
} 
more detail later, here is one: Chapter 3 is entitled "The Concept of Law," thus seemingly participating in the same conceptual inquiry that dominated Hart's book bearing that title. But the chapter opens with an epigraph from Roscoe Pound that gives us a hint on what Fuller thought was the proper way of answering the question "what is law?": "ideas of what law is for are so largely implicit in ideas of what law is, a brief survey of ideas of the nature of law from this standpoint will be useful." ${ }^{6}$ As we shall see, Fuller's answer to the question "what law is for?" is thoroughly normative, which implies that he thought that the answer to the "conceptual" question "what is law?" was itself the conclusion of a normative, political, argument. ${ }^{7}$ That is the conclusion I ultimately hope to establish. To get to there, however, I will have to start by examining Fuller's views on freedom.

\section{Freedom through Constraint}

Freedom was a topic that occupied Fuller's thought for many years. He has written several essays specifically on it, ${ }^{8}$ and he has made many additional remarks on the topic that are scattered throughout his other writings. Despite the significance Fuller obviously attached to the topic, these essays are now forgotten even by those sympathetic to his ideas, and their relationship to his jurisprudential ideas rarely explored. ${ }^{9}$ Fuller's starting point in thinking about freedom is that no meaningful action is

\footnotetext{
${ }^{6}$ See Lon L. Fuller, The Morality of Law 95 (rev. ed. I 969) (quoting Roscoe Pound, An Introduction to the PHILOSOPHY OF LAW 25-26 (1 922)). Interestingly, Fuller omits the words "from this standpoint" from his quote, suggesting perhaps that he thought that this was the only standpoint for thinking about this question.

${ }^{7}$ Fuller's other epigraph on the same page is similarly revealing: "Forgetting our objectives is the most frequent of all acts of stupidity." Friedrich Nietzsche, Human, All Too Human: A Book for Free Spirits $\$ 2.2 .206$ at 360 (R.J. Hollingdale trans., I 986) (I 879-80). (Fuller quotes it in the original German.) Fuller had used these words, to similar effect, already in L.L. Fuller \& William R. Perdue, Jr., The Reliance Interest in Contract Damages (pt. I), 46 YALE L.J. 52,52 ( 936 ).

${ }^{8}$ See Lon L. Fuller, Freedom-A Suggested Analysis, 68 HARV. L. Rev. 1305 (1955) [hereinafter Fuller, Suggested Analysis]; Lon L. Fuller, Freedom as a Problem of Allocating Choice, i I 2 PROC. AM. PHIL. SOC'Y i I ( 1968 ) [hereinafter Fuller, Allocating Choice]; Lon L. Fuller, Some Reflections on Legal and Economic Freedoms-A Review of Robert L. Hale's "Freedom Through Law", 54 COLUM. L. REv. 70 (1954) (book review) [hereinafter Fuller, Reflections]; cf. Lon L. Fuller, Irrigation and Tyranny, 17 STAN. L. REV. 102 I (1965) [hereinafter Fuller, Tyranny]. In addition, in I 958 Fuller delivered a series of three lectures at Louisiana State University with the title "Freedom and the Nature of Man." Of those, the only remaining text is of the first lecture. See Lon L. Fuller, The Case Against Freedom, in The Principles Of Social Order: Selected ESSAYS OF LON L. Fuller 3 I 5 (Kenneth I. Winston ed., rev. ed. 200 I) [hereinafter Fuller, Case Against Freedom].

9 The neglect of Fuller's work on freedom is most notable in ROBERT S. SUMMERS, LON L. FULLER (1984). This book seeks to provide a critical survey and general assessment of the entirety of Fuller's thought, yet it has barely a paragraph on his writings on freedom and it never ties them to his legal theory. I know of only three articles that contain any extended discussion of Fuller's views on freedom. See Kenneth I. Winston, Legislators and Liberty, I 3 LAW \& PHIL. 389 ( 1994 ); Jeremy Waldron, Why Law-Efficacy, Freedom, or Fidelity?, I 3 LAW \& PHIL. 259 (1994); Jamie Cassels, Lon Fuller: Liberalism and the Limits of Law, 36 U. TORONTO L.J. 3 I 8 (1986) (reviewing SUMmerS, supra). Winston keeps Fuller's discussion of freedom separate from Fuller's theory of law (so much so that he does not mention The Morality of Law in his essay). Waldron explores some possible links between Fuller's views on law and on freedom, but his conclusion on such links is
} 
possible without constraints. He makes this point many times and he takes it to be of general applicability. It is only the constraints of language, for example, that turn the noises we emit into meaningful expressions, thereby giving us the enormous freedom that comes with communication. Less dramatically, it is only the constraints imposed by the rules of football that turn otherwise aimless movements into a meaningful activity, thereby making the discussion and execution of various strategies, formation and so on, possible. ${ }^{10}$

These constraints, said Fuller, create the social environment that makes interaction possible:

To interact meaningfully men require a social setting in which the moves of the participating players will fall generally within some predictable pattern. To engage in effective social behavior men need the support of intermeshing anticipations that will let them know what their opposite numbers will do, or that will at least enable them to gauge the general scope of the repertory from which responses to their actions will be drawn. We sometimes speak of customary law as offering an unwritten "code of conduct." The word "code" is appropriate here because what is involved is not simply a negation, a prohibition of certain disapproved actions, but also the obverse side of this negation, the meaning it confers on foreseeable and approved actions, which then furnish a point of orientation for ongoing interactive responses. ${ }^{11}$

It is these meaningful interactions that explain what is valuable about freedom. And it is this view that explains why Fuller wrote in an unpublished typescript that "forms"-norms and practices within whose constraints individuals act- "liberate." ${ }^{2}$ For Fuller this point had enormous significance in terms of its stakes: "if we are to live with our fellows, our actions...cannot be effective unless they take place within some framework that brings them into meaningful relation with the actions of others." ${ }^{13}$ It also had enormous significance in terms of its scope: It pertained to "rules, procedures, and institutions," it relied on insights from different disciplines "cut[ting] across law, politics, economics, sociology, and ethics, and even includ[ing] systems of play." ${ }^{14}$ It was relevant to understanding "all

largely negative. See Waldron, supra, at 267-68, 272. Only Cassels draws some links between Fuller's ideas on freedom and his legal theory. See Cassels, supra, at 330-40. His discussion, however, is quite different from my own.

${ }^{10}$ Years later, essentially the same idea, using similar terminology to Fuller's, was found in STANLEY FisH, THERE Is NO

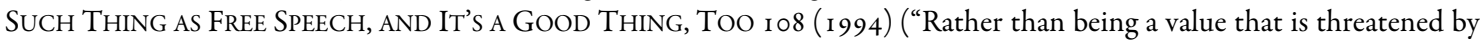
limitations and constraints, expression, in any form worth worrying about, is a product of limitations and constraints....Indeed, the very act of thinking of something to say...is already constrained...by the background context within which the thought takes its shape."). Fish's dramatic claim in the title of his book turns out to be the much more modest (and as shown here, familiar) idea that some constraints are necessary for freedom.

${ }^{11}$ Lon L. Fuller, Human Interaction and the Law, i 4 AM. J. JURIS. I, 2-3 (1969) (emphasis added).

${ }^{12}$ A photo of that typescript is reproduced in Kristen RundLe, Forms Liberate: ReClaiming the JuRISPRUdENCE LON L FULLER, at ii (2012). Rundle is obviously aware of the significance of these words to Fuller-after all, they make up the title of her book. But while she pays attention to the significance Fuller attached to "forms," she attaches much less significance to the second word. Like most commentary on Fuller, she does not consider Fuller's writings on freedom and their possible connection with his legal theory.

${ }^{13}$ Fuller, Case against Freedom, supra note 8, at 320-2 I.

${ }^{14}$ Lon L. Fuller, Human Purpose and Natural Law, 53 J. PHIL. 697, 704 (1956). 
forms of social order," including "contract, adjudication, the majority principle, and the three-strike, four-ball rule." 15

Fuller drew important normative conclusions from this idea. It provided for him a justification for the welfare state and for rejecting libertarian views on the appropriate limits on government. ${ }^{16}$ The idea of the liberating force of forms also recurred in his writings on a diverse range of areas in law. He relied on it to explain law in general (and in contradistinction from other forms of social order like contract, adjudication, and so on), ${ }^{17}$ as well as particular aspects within law. Fuller wrote at length about the "forms" of adjudication and compared and contrasted them with the "form" of mediation. ${ }^{18}$ More narrowly, he famously used this idea of form to explain the role of consideration in contract formation. ${ }^{19}$

How does all this relate to other perspectives on freedom? A hint appears in a brief handwritten comment that accompanies the words "forms liberate" on his unpublished typescript. The words read: "Cf negative concept of freedom." ${ }^{20}$ Fuller associated the negative concept of freedom with Mill's $O n$ Liberty and he defined it as "leaving a man alone,...not imposing restraints on him."21 Fuller considered

${ }^{15} \mathrm{Id}$.

${ }^{16}$ See Fuller, Reflections, supra note 8, at 77-78. Fuller writes there: It is a great mistake...to equate the forces of the market with natural forces. In fact the economic market is an artificial acquisition that it has taken mankind centuries to achieve. The most perfect markets are not those that arise spontaneously, but those that are the result of deliberate organization and planning. To make such a market function effectively, it may be necessary to impose restraints on economic freedom, as by restricting certain kinds of dealings when the market is closed. It may also be essential to establish a governmental surveillance of the market (by the SEC, for example) to prevent the exploitation of advantages by "insiders" and to insure that it will function as a market is supposed to function.

Id. (footnote omitted). See also id. at 7 I (endorsing "steeply graduated income tax"). Fuller also favored centrally organized medical care over the one "thought of, and in part organized, after the market pattern." Fuller, Suggested Analysis, supra note 8, at I 32 I. I therefore disagree with claims that Fuller had libertarian "attitudes" or "inclinations." See Nicola Lacey, Out of the 'Witches' Cauldron'?, in The Hart-Fuller Debate in the Twenty-First Century i, 26 (Peter Cane ed., 2010) [hereinafter HART-Fuller DeBATE]; Cassels, supra note 9, at 339-40. Though Fuller admitted to being heavily influenced by the ideas of Michael Polanyi, he departed from them in important respects. See Fuller, Suggested Analysis, supra note 8, at I 320 n.7; see also LON L. Fuller, The Problems Of JURISPRUdenCE 700 (temporary ed. 1949) (distancing himself from "individualism"), and the text accompanying notes 25-26, infra.

${ }^{17}$ See Lon L. Fuller, The Role of Contract in the Ordering Processes of Society Generally, in THE PRINCIPLES OF SOCIAL ORDER, supra note 8, at i 87, i 88-90.

${ }^{18}$ See Lon L. Fuller, The Forms and Limits of Adjudication, 92 HARV. L. REV. 353 (1978); Lon L. Fuller, Mediation-Its Forms and Function, 44 S. CAL. L. REV. 305 (1971) [hereinafter Fuller, Mediation].

${ }^{19}$ Lon L. Fuller, Consideration and Form, 4I COLUM. L. REV. 799 (I94I).

${ }^{20}$ See RUNDLE, supra note I 2, at ii. Rundle reports the page comes from Fuller's notes to his "Reply to Critics." See id. at I. This suggests that at some point Fuller did think of drawing an explicitly link between his views on freedom and his ideas in The Morality of Law, but his thoughts on this matter did not make it to the published version of his Reply.

${ }^{21}$ Fuller, Allocating Choice, supra note 8, at 103. 
Mill's conception of freedom highly problematic for several reasons. Mill emphasized the idea of individual autonomy, but Fuller saw this "ideal of freedom" as the aspiration for "li[f]e as a hermit." He challenged it by saying that "[f] or most of us the life of freedom must be as members of society." 22 For related reasons, and in sharp contrast with Hart, Fuller also rejected the idea that survival was the most fundamental desire shared by all humans; the true basic desire, he thought, was "maintaining communication with our fellows," 23 not just as "a means of staying alive," but also as "a way of being alive," at least in the only kind of life Fuller thought was worth living: "I doubt if most of us would regard as desirable survival into a kind of vegetable existence in which we could make no meaningful contact with other human beings." ${ }^{24}$ Freedom was therefore valuable only to extent that it allowed and promoted these ends.

This may strike some readers as an unfair characterization of negative freedom. Such writings often tie freedom with the ability to choose and so associate greater freedom with a larger number of available options. But Fuller had little sympathy for this idea as well. Fuller found Mill's individualistic conception of freedom "strangely blind to the fact that... $[\mathrm{t}]$ he choices a man can make without requiring collaborative social effort for their realization are trivial." ${ }^{25}$ Fuller went further: even if it were possible, he thought this world of "unlimited choice," for reasons now supported by empirical evidence, utterly undesirable. ${ }^{26}$

Thus, one of the striking features of Fuller's conception of freedom is that it is thoroughly social, and there is little to nothing in it about individual autonomy. ${ }^{27}$ Consequently, it gives a central role to institutions, including legal and political institutions, as means for creating the environment in which freedom can flourish and be of value for human flourishing. When such institutions were in place negative freedom was not irrelevant, but Fuller considered it of relatively marginal significance for the law, because it dealt only with situations that did not involve the creation of any structuring restraints. Fuller proposed the domain of sexual relations as one of the rare areas where there was no need "to make arrangements for the sexual freedom of man; nature has seen to that.. ${ }^{28}$ Even here, notice, the

${ }^{22}$ Fuller, Case Against Freedom, supra note 8, at 320.

${ }^{23}$ FULLER, supra note 6, at I 85.

${ }^{24} I d$. at 186 . Hence Fuller's conclusion: "can we derive from the morality of aspiration itself any proposition of law that is substantive, rather than procedural, in quality?...I would find it in the injunction: Open up, maintain, and preserve the integrity of the channels of communication by which men convey to one another what they perceive, feel, and desire." Id. at I 84, I 86 .

${ }^{25}$ Fuller, Suggested Analysis, supra note 8, at I 3 I 2.

${ }^{26} I d$. at I 3 I I. The empirical data referred to in the text is summarized in BARRY SCHWARTZ, THE PARADOX OF CHOICE: WHY MORE Is LESS (2004).

27 See Fuller, Case Against Freedom, supra note 8, at 321-22 (distinguishing freedom in his sense from the sense of "freedom as self-liberation," "in which a man can achieve freedom by his own efforts").

${ }^{28}$ Fuller, Suggested Analysis, supra note 8, at 13 I I. Michel Foucault would probably have said that Fuller was too hasty in this conclusion. 
domain was not devoid of restraints, rather they were provided by nature. In any event, outside of such unusual cases, the real normative problem with freedom was different:

When we discuss freedom as a problem of law, or politics, or economics, or ethics, we are really addressing ourselves to the question: How can the freedom of human beings be affected or advanced by social arrangements, that is, by laws, customs institutions, or other forms of social order that can be changed or preserved by purposive human actions $?^{29}$

Fuller's answer to this question is the key to understanding the way he connected his ideas on freedom to his views on law.

\section{Reinterpreting The Morality of Law}

At its most general, my claim in this essay is that the ideas in The Morality of Law make more sense if read together with these political ideas. If I am right, one reason why this book has often been treated so harshly has to do with the fact that Fuller did not do enough to highlight these links. It may be (although this is mere speculation) that Fuller believed he could beat the conceptual positivist at his own game, that he could show that even on narrow conceptual grounds legal positivism fails. And he may have chosen this narrower line of attack since he did not want to be seen as engaging in a question that some might argue could peacefully co-exist alongside the conceptual inquiry. I will not address here the question whether conceptual jurisprudence can be challenged even on its own, or whether one can find in The Morality of Law a challenge to legal positivism that does not depend on Fuller's views on freedom. ${ }^{30}$ In this section I try to spell out in more detail how what Fuller says in The Morality of Law makes sense if its ties to Fuller's political ideas on freedom are made explicit. In subsequent sections I turn to the question whether this view can also be seen as a challenge to the possibility of conceptual jurisprudence.

\section{(a) The Structure of Fuller's Argument}

To see in what way my attempt to tie Fuller's argument to his ideas on freedom is different from the prevailing understanding of Fuller's account, let me present what I take to be the general outline of the accepted interpretation of Fuller's challenge to legal positivism:

(i) Law as a conceptual matter has a certain function (law is a functional kind).

(ii) Law's function establishes its nature.

(iii) Law's function also entails certain constraints on legality, the principles of legality.

(iv) The principles of legality are law's "internal morality."

\footnotetext{
${ }^{29} \mathrm{Id}$. at $\mathrm{I} 309$.

${ }^{30}$ Elsewhere I have suggested that a Fuller-inspired argument can give us reasons to doubt Hart's account even on its own terms and without invoking Fuller's ideas on freedom. See Dan Priel, Reconstructing Fuller's Argument Against Legal Positivism, 26 CAN. J.L. \& JURISPRUDENCE 399 (2013).
} 
(v) From (iv) it follows that there is a necessary connection between law and morality.

(vi) Legal positivism is the thesis that there is no necessary connection between law and morality.

(vii) From (v) and (vi) it follows that legal positivism is false.

Legal positivists have responded in different ways. Some have rejected (i), telling us that " $\mathrm{t}]$ here is no social function, nor any combination of social functions, that distinguishes law from any of its near neighbours." ${ }^{31}$ Some have attacked (ii) with the claim that "while no one would doubt the importance of knowing why we should have law...this cannot be an argument for the thesis that the law is one way or another." ${ }^{32}$ Still others have rejected the idea that the principles of legality have anything to do with morality, ${ }^{33}$ a view that amounts to a rejection of (iv). Finally, recently, many legal positivists have come to think (vi) is false. ${ }^{34}$

There is much to say about each of these responses, but that is not the strategy I adopt here. Based on Fuller's work on freedom I will present a different, political, argument on his behalf. The argument in outline looks like this:

(I) Freedom does not consist in being left alone or with the removal of constraints, but with the creation of means that make purposive action possible.

(2) From ( $\mathrm{I}$ ): constraints are necessary for meaning and thereby for freedom.

(3) There are several forms of constraint (forms of social order). Law is one of them. Law is thus a means for generating human freedom.

(4) Law typically creates constraints by way of general "rules" that (should) assist individuals in regulating their relationship with each other.

(5) When someone is subject to a rule imposed by another she has a valid concern over its legitimacy, over the right of the rule-maker to enforce it. (When it lacks such legitimacy in the context of a state we typically call it a "tyranny.") ${ }^{35}$

(6) Law is a particular kind of rule-governed practice: it is in the form of an ongoing activity or enterprise grounded in the idea of reciprocity.

(7) (6) explains the way of addressing the problem raised in (5) with relation to law: law is also legitimated in a unique way, not shared by other rule-giving practices. ${ }^{36}$ The unique legitimating requirements of law (derived from the idea of reciprocity) are the eight principles of legality.

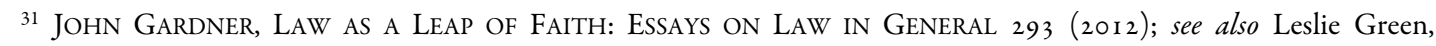
Introduction to HART, CONCEPT, supra note 4 , at $\mathrm{xxxv}$ (ascribing this view to Hart).

32 Joseph RaZ, Between Authority and Interpretation: On the THEORY OF LAW AND Practical ReasON 384 (2009); cf. HART, CONCEPT, supra note 4, at 248-49.

${ }^{33}$ H.L.A. Hart, Book Review, 78 HARV. L. REV. I 28 I , 286 ( 1965) (reviewing FUlLER, supra note 6).

${ }^{34}$ See, e.g., GARDNER, supra note 31, at 254; RAZ, supra note 32, at 176-78. Other legal positivists rejecting (vi) are cited in Priel, supra note 30, at 4 I I n.44.

${ }^{35}$ Fuller himself uses the term "lawless violence" as a contrast to law. See FULLER, supra note 6, at io8. Fuller also implicitly contrasts law here with mediation, which Fuller characterizes by "its capacity to reorient the parties toward each other, not by imposing rules on them but by helping them to achieve a new and shared perception of their relationship." Fuller, Mediation, supra note 18 , at 325 . Because of its different form, the problem of legitimacy is solved differently in the case of mediation. See id. at 3 I 4-1 5 
(8) It is because of (7) that adherence to the requirements of legality makes law possible: they are law's "natural law." Without them the reciprocal nature of law (see (6)) becomes impossible.

(9) From (8) it follows that a putative legal system that fails to abide by these principles is not simply a bad legal system, but in some sense no law at all.

It should be clear that whatever faults this argument may contain, it is immune to the counterarguments presented to the conceptual argument attributed to Fuller. And I hope to show in what follows, it is not a conceptual argument (or, if you wish, it establishes conceptual conclusions on normative grounds, rather than the other way around). The rest of this section is dedicated to assessing it in more detail in relation to some of Fuller's famous ideas. I will try to show how and where they fit within the argument just outlined. I hope to show that even if not ultimately convincing, these ideas are not as odd as many of Fuller's critics have found them.

\section{(b) The Link with Freedom}

Freedom figures twice in the argument I reconstructed on behalf of Fuller. It first appears there directly in (I), as the starting point for the argument explicating the value of law, but in this respect, law is no different from any other constraint. It is less obvious, but freedom plays a role in (7) as well. Showing this is the main task of section IV below, but in general outline the idea is this: Law is one of the institutions that provide the constraints that make freedom possible. One of the characteristic features of law, unlike say, joint purposive activity done with a common end in mind, is that law (or at least modern law) typically operates by subjecting humans to the governance of rules imposed by others. As a result it is subject to concerns of legitimation of the rule-maker. We see these concerns in the way we distinguish between brute demands backed by force and a legitimate, or at least potentially legitimate, demand (where the judgment of legitimacy is made relatively independently of the content of the demand). As we shall see, this is related to a fundamental distinction between law and tyranny. According to Fuller to avoid tyranny the relationship between the rule-maker and rule-subject must be grounded in some idea of reciprocity. The principles of legality serve a necessary role in creating such a reciprocal relationship, such that when they are absent the result, even if it has the superficial appearance of law, is tyranny.

The conclusion, whether warranted or not, is not a claim about prevailing linguistic usage, it is not a claim about what people have in their head when they talk about law, it is not an irrefutable claim about what "the concept of law" just is. It is the conclusion of a normative argument. It is also not conceptual at further remove. It is not based on any alleged elucidation of the concept of freedom means, but on what makes freedom a value worth pursuing.

\footnotetext{
${ }^{36}$ See FULLER, supra note 6, at 2 I $0-1$ I. See also the discussion in note 42 and section III.(d), infra.
} 


\section{(c) Subjecting Human Conduct to the Governance of Rules}

Fuller did not think that there was any particular purpose that law was concerned with: he repeatedly says that law is indifferent between numerous different aims. ${ }^{37}$ He did believe, however, that law had one general aim that he described, somewhat cryptically, as "subjecting human conduct to the governance of rules." ${ }^{38}$ Though this expression sounds as though it is nothing but a long-winded way of saying "rule following," 39 Fuller rejects the picture of law as primarily concerned with either guidance of conduct (on part of the lawmakers) or rule-following (on part of the law-subjects). Mere rule following, he says, is the mark of "managerial direction" between superiors and subordinates, which he distinguishes from law. Unlike managerial disretion, which seeks to promote a particular aim set by the manager, law's function is not to tell people what to do or not to do but to create "an orderly interaction among citizens and furnish dependable guideposts for self-directed action." 40 Corresponding to this substantive difference there is also a difference in the "internal morality" or "natural law" of managerial discretion and law. He repeatedly refers to law as the subjection of humans to the governance of rules, and is similarly restrictive in treating as the full set of the principles of legality as unique to law. While five of the eight principles of legality are "quite at home in the managerial context," the other three are unique to law. ${ }^{41}$

Why is that? One aspect of the "subjecting humans to the governance of rules" that has not received sufficient emphasis is that of "subjecting," namely that of having the "governance of rules" created and imposed by other than those who are subjected to them. The rules in question are often imposed without consent. For these rules to have normative force-to be different from both mere pronouncements that lack normative force ("all must pay twenty per cent of their salary to Dan Priel") and from edicts of the tyrant (the force of whose rules comes from threat) - they must be legitimate. Legality thus does not, or not merely, require looking to the past of legal norms, to the see whether they have been promulgated according to a particular "rule of change" in accordance with a "rule of recognition"; it requires considering their present assessment beyond that goes beyond legal rules. That present involves the maintenance of an ongoing existence of a kind of reciprocity between lawgiver and

\footnotetext{
${ }^{37}$ See, e.g., id. at 96, I 53 .

${ }^{38} I d$. at 46, 74, 96, 106, I 24, 162.

${ }^{39}$ See Waldron, supra note 9, at 261, for what looks like this reading of this expression.

${ }^{40}$ FULLER, supra note 6, at 229; see also Fuller, supra note I I, at 26 ("law as serving the purpose of putting in order and facilitating human interaction”). On the difference between Hart and Fuller on this regard see note i 10 , infra.

${ }^{41}$ FULLER, supra note 6, at 208. Waldron claims to the contrary that Fuller believed the principles of legality "are desiderata not just of law but of any 'system for subjecting human conduct to the governance of rules'." Waldron, supra note 9, at 261 (quoting $i d$. at 46). But the passage from these words come does not support this interpretation. As already mentioned, Fuller quite clearly distinguishes law from “managerial direction," see FULLER, supra note 6, at 207-09, claiming that they have different internal moralities. The same conclusion is derived from statements that specifically mention law in this way. See id. at I24. As I try to show further in the text below, Fuller's ideas make more sense with this contrary assumption. See also Fuller, Tyranny, supra note 8, at 1028-29.
} 
subject "that is part of the very idea of a functioning legal order." ${ }^{22}$ This substantive idea finds its counterpart in the three principles of legality that are unique to law, as their role is to guarantee "the existence of a relatively stable reciprocity of expectation between lawgiver and subject is part of the very idea of a functioning legal order." ${ }^{43}$ It is because of this that Fuller says that his view "treats law as an activity and regards a legal system as the product of a sustained purposive effort." ${ }^{\prime 4}$ A legal order or a legal system is not the sum total of rules, but (also, and distinctly) an ongoing social practice. Correspondingly, living in a political community governed by law is a continuous, reciprocal enterprise. It requires constant "work" to sustain it. It is this aspect of law missed by those theories that focus only on the rule following aspect of "subjecting humans to the governance of rules."

\section{(d) The Internal Morality of Law}

One of the best known (and contested) ideas in The Morality of Law is that law contains its own internal (or inner) morality. To fully understand this term we must consider four questions: First, in what sense are the principles of legality "internal" to law? Second, in what sense are they a "morality"? Third, in what sense are they "of law," or in other words, in what sense are they unique to law? And fourth, what does it mean that a significant enough departure from the principles of legality results in something that is "not simply bad law, but not law at all" ?45 In this subsection I will answer the first three questions; I will address the last one in subsequent sections.

The answer to the first question is fairly simple. The principles of legality are "internal" in that they do not assess laws on their success in promoting whatever goal the law was designed to deal with (be it the reduction of crime or pollution, the redistribution of wealth, the improvement of educational standards, or any other such goal); rather they are internal in the sense that they are concerned with the question of the pursuit of these goals through law, i.e. through the distinct means of "subjecting humans to the governance of rules."

Turning to the second question, a familiar criticism of this argument, one made more-or-less similarly by Hart, Dworkin, and Raz, is that the principles of legality are a matter of efficiency, not morality. Hart offered the example of the "internal morality of poisoning" as a reductio of the idea. ${ }^{46}$ We now have the tools to see why this argument misfires. It is worth noting first that all those who thought they have shown how Fuller foolishly overlooked an obvious but devastating logical

42 FULLER, supra note 6, at 209.

${ }^{43} \mathrm{Id}$; see also id. at 228-29 (commenting on the significance of fulfilling expectations). Interestingly, Fuller also says that law is different from managerial direction in that it is primarily there for the purpose of "setting the citizen's relations with other citizens and only in a collateral manner his relations with the seat of authority from which the rules proceed." Id. at $207-08$.

${ }^{44} I d$. at 106 (emphasis added). Fuller also talks of the need to understand law "in terms of the activity that sustains it." Id. at I 29; $c f . i d$. at $\mathrm{r} 20-22$ (analogizing "the activity we call law" to the "scientific enterprise").

${ }^{45} \mathrm{Id}$. at 197.

${ }^{46}$ Hart, supra note 33 , at I 286. 
implication of his position have not noticed that Fuller has made the point himself, before them. In The Morality of Law he talks of the "natural laws of carpentry, or at least those rules respected by a carpenter who wants the house he builds to remain standing and serve the purpose of those who live in it." ${ }^{47}$ Almost a decade earlier Fuller has noted a possible objection to his view, that it "confuse[s] the question of ultimate value with that of selecting the most effective means for realizing an immediate purpose". As he put it there, "[t] hat there are good and bad ways of opening clams leaves untouched the question whether opening clams is itself an activity entitled to be called good." 48 In another article from around that time he was clear about the wide scope of his idea: "any form of social order contains...its own internal morality. Thus, we may judge football by an external standard and say, 'Football is a good game,' but we may also judge it by standards drawn from its internal requirements and say 'Football will become impossible if this sort of thing is allowed to go on." ${ }^{49}$ This, for Fuller, was a thesis that "range[s] from the most trival $[s i c]$ to the most crucial that human beings can face." Most strikingly, writing in 1949 Fuller saw no difficulty in talking even about the "natural laws of a dictatorship." 51

By focusing only on one manifestation of it - the internal morality of law-we inevitably fail to understand the full significance of the idea of internal morality. The example of football helps clarify what Fuller meant by it. The "natural laws" of football are not the constitutive rules of the practicethey are not, say, the rules that determine the size of a football pitch or the number of players per team. If that had been Fuller's meaning, his argument would have amount to the pointless attempt (and, unless one is a Platonist about football, devoid of an answer) to identify the point at which changing the rules of football results in something that is not football anymore. What Fuller meant by the notion of internal morality is something else: here are certain precepts, typically only implicitly acknowledged, that have to be maintained for an activity to have potential for succeeding in bringing about the very goals set up for the activity by those engaged in it. When this is understood it no longer seems so strange to talk even of the natural laws of a dictatorship. The example is also useful because it highlights that it is wrong to think Fuller was engaged in the conceptual or classificatory exercise often attributed to him.

All this highlights the tension within the term "internal morality." Even if one accepts that all practices have these kinds of "natural laws," it might seem odd to call all of them a "morality." Much of the resistance to Fuller's idea could have been avoided if this idea had been formulated slightly

${ }^{47}$ FULLER, supra note 6, at 96.

${ }^{48}$ Fuller, supra note i 4, at 699 . Not only the spirit of Hart's challenge is similar, even its letter is. Compare Fuller's words quoted in the text with Hart's challenge: "to call [the] principles of the poisoner's art 'the morality of poisoning' would simply blur the distinction between the notion of efficiency for a purpose and those final judgments about activities and purposes with which morality in its various forms is concerned." Hart, supra note 33 , at 1286.

${ }^{49}$ Fuller, supra note I 4 , at 704.

${ }^{50} \mathrm{Id}$. at 705 .

${ }^{51}$ FULLER, supra note 16 , at 725. 
differently: all practices have their "natural laws" (which are not necessarily moral), but in the case of law (and possibly other social practices) these natural laws are moral in nature. ${ }^{52}$ The reason why the natural laws of law are moral in nature has to do with their specific content. More precisely, the natural laws of law are moral because they play a role in legitimating the subjection of humans to the governance of rules imposed by others without the rule-subjects' consent. This is not a concern in the case of a practice like football.

All this, together with what I have already said in the previous subsection also answers the third question posed above, namely the sense in which the internal morality unique to law. To repeat briefly, the full set of the eight principles of legality establish the kind of reciprocity between lawgiver and subject "that is part of the very idea of a functioning legal order." ${ }^{.53}$ One point not mentioned before is how this idea of reciprocity explains the centrality of governance of rules (rather than particular orders) to Fuller's account. Rules are essential for the creation of expectations, themselves important for generating the reciprocity he took to be essential for law: "the citizen cannot orient his conduct by law" when the orders "confront[] him merely with a series of sporadic and patternless exercises of state power." " ${ }^{\prime 4}$ This again highlights the role of the principles of legality in establishing the reciprocity Fuller thought was necessary for legitimacy. This is very different from the view that the principles of legality are there only for the sake of efficient transmission of edicts to be followed.

\section{Freedom and The Morality of Law}

In the course of The Morality of Law Fuller distinguishes between law and managerial direction, between law and morality, ${ }^{55}$ between law and lawless violence, ${ }^{56}$ between the law of a generally just regime and what may look like law but is what one finds in evil regimes, ${ }^{57}$ even between law and contract. ${ }^{58}$ All this lends credence to the view that Fuller participated here in the kind of "conceptual" or "classificatory" enterprise that has dominated analytic jurisprudence in the last fifty years. This, I think, is quite clearly a mistake.

\footnotetext{
52 In a letter to Hart Fuller was willing to abandon the terminology of "internal morality" in favor of "trusteeship" (which Fuller had already used in FuLLER, supra note 6, at 43). Letter from Lon Fuller to H.L.A. Hart (Oct. I 8, I 995 ), Lon L. Fuller Papers, Box 3, Folder 1 4, quoted in RUNDLE, supra note i 2, at io7.

${ }^{53}$ FULLER, supra note 6, at 209.

${ }^{54} I d$. at $\mathrm{I}$ I 0 . This point is also relevant for highlighting another issue which I will not explore in this essay but on which Fuller is at variance with much contemporary analytic jurisprudence, namely the recognition that legal theory should talk of a law as a human enterprise, made for humans and their limitations. On this see also id. at I $48-5 \mathrm{I}$.

${ }^{55}$ See id. at 203-05.

${ }^{56}$ See id. at 108.

${ }^{57}$ See id. at 40-4I, I 57-58.

${ }^{58} \mathrm{See} i d$. at $126-29$.
} 
Fuller does indeed distinguish between law and nonlaw, but his distinction is the conclusion of a political argument that ties law with legitimacy, legitimacy with reciprocity, and reciprocity with freedom. I have discussed the first two ties in the previous section. This section deals with the third. Along the way I hope to show that Fuller develops here an idea with a long history in political thought, and one that has had particular resonance in the history of American politics. In the next section I consider the implications of this perspective to the methodology of general jurisprudence.

\section{(a) Fuller's Republicanism}

One would be forgiven for thinking that every aspect of Fuller's decade-long exchange with Hart has already been comprehensively discussed. But let me add a chapter to that exchange, one that as far as I know, has so far escaped attention. In one of Fuller's essays on freedom, published in i 968 (i.e., a year before the publication of the "Reply to Critics"), he wrote:

An English scholar, who spent a year in this country, on his return home gave a talk on one of BBC's radio programs attempting a kind of anthropological appraisal of the two cultures, the American and the English. He reported that the two peoples hold two quite different views of the nature of freedom. To the Englishman the primary meaning of freedom is to be left alone; the American-to quote our visitor's phrasing-conceives of freedom as "the opportunity to participate in decision-making processes." 59

Though left unnamed, the English scholar in question is no other than H.L.A. Hart. The passage Fuller quoted comes from a little-known, brief piece Hart published upon his return to Britain after his year at Harvard. The relevant passage reads in full:

For us [the English], surely, liberty is this: that there is a circle round each man, inside which he can do as he pleases, and it is no concern of others; this is the liberty the Englishman has inside his house and garden and behind its hedges. I think that this as an ideal makes little appeal to an enormous number of Americans; I believe you can find what the American means by liberty by looking at the Constitution of an American State: In the State of Massachusetts the Constitution provides that any member of the public may introduce a measure into the Legislature and argue for it before committees. And it seems to me that this is what An American means by liberty; the right to take part in what he would call 'the decision-making process. ${ }^{60}$

The question to be answered about these two views is not which better captures the "correct" concept of freedom, a debate that has no answer. The debate between these two views is which view (concept,

${ }^{59}$ Fuller, Allocating Choice, supra note 8, at 103. Fuller slightly misquotes Hart. The accurate quote is in the text accompanying the next note. Fuller draws here on his own (at the time unpublished) Fuller, Case Against Freedom, supra note 8 , at 323 .

${ }^{60}$ H.LA. Hart, A View of America, 59 LISTENER 89, 89 (1958). Hart echoes here observations made more than a century earlier by another visitor to the United States. See AlEXIS DE TOCQUEVILlE, DeMOCRACY IN AMERICA 84-85 (Gerald Bevan trans., 2003). In Priel, supra note 30, at 408-09, I have briefly suggested that some central features of Hart's account are best explained under the assumption that Hart implicitly relied on the "English" conception of freedom. See also the text accompanying notes $107-110$, infra. 
conception, understanding, notion, idea) of freedom is more normatively attractive. In defense of the "American" view Fuller wrote:

[I]f society seriously left a man alone, and thrust none of its facilities on him, he would starve to death. It might also be observed that the original meaning of the words "liberty" and "freedom" was not absence of constraint, but enfranchisement. To be free, to enjoy liberty, was-in the original significance of those terms - to be admitted to effective participation in the affairs of the family, the tribe, or the nation. And meaningful participation in affairs requires that one accept, and act through, the forms of procedure that make possible a functioning whole. ${ }^{61}$

Leaving aside Fuller's lexicographic claim, Fuller makes here two points that should by now be familiar. The first is that being left alone cannot be a desirable normative goal, because its full realization would not lead to a good life, but to death. The second point is that freedom is better understood as participation, and participation can be meaningful only it is structured within certain "forms of procedure."

In many respects these ideas draw on a particular conception of freedom, one that in recent years has regained prominence under the banner of "republican" or "neo-Roman" freedom. ${ }^{62}$ There are several hints that this is the tradition Fuller is drawing on. At the most superficial level, there are the sources Fuller relies on in his work. In The Morality of Law itself Fuller discusses some of the historical origins of his ideas and he points to the works of English Leveller John Lilburne, ${ }^{63}$ and republican American framers like Alexander Hamilton. ${ }^{64}$ His prime example comes from Edward Coke, whose ideas have important affinities with republican notions of freedom, in particular the idea of freedom as the product of law. ${ }^{65}$

There are more important similarities. As we have also seen Fuller's conception of freedom is first and foremost a political concept: Fuller does not talk of freedom in terms of personal autonomy, but as

${ }^{61}$ Fuller, Allocating Choice, supra note 8, at 103 ; see also Lon L. Fuller, Law as an Instrument of Social Control and Law as a Facilitation of Human Interaction, 1975 BYU L. REV. 89, 92 (The word enfranchise "may mean, depending upon the context, to be freed from slavery, to acquire the right to vote, or to become vested with the capacity to bind oneself legally by a contractual arrangement.").

62 See generally Philip Pettit, Republicanism: A Theory of Freedom And Government (i 997); Quentin SKINNER, LibERTY BEFORE LIBERALISM I-99 (1998).

${ }^{63}$ A quote from Lilburne is the epigraph for chapter 2 of The Morality of Law. See Fuller, supra note 6, at 33. Fuller returns to Lilburne in his "Reply to Critics," id. at 217-18. For Lilburne's endorsement of a republican conception of freedom see QUENTIN SKINNER, HOBBES AND REPUBLICAN LIBERTY I 53 (2008). More generally on the relationship between the Levellers (including Lilburne) and republicanism see Nigel Smith, Popular Republicanism in the I6sos: John Streater's 'Heroick Mechanicks', in Milton and Republicanism 137 (David Armitage et al. eds., I 995); Samuel Dennis Glover, The Putney Debates: Popular Versus Élitist Republicanism, i64 PAST \& PRESENT 47, 47-50 (1999). Even those who argue for a difference between the Levellers' ideas and republicanism stresses the sense in which for Lilburne freedom was the product of law. See Rachel Foxley, John Lilburne and the Citizenship of Free-Born Englishmen', 47 HIST. J. 849, 857-58, 873 (2004).

${ }^{64}$ See FULLER, supra note 6, at 99-102.

${ }^{65}$ See Foxley, supra note 63, at 859-62, on Coke's influence on Lilburne. 
a value of significance for people within a political community. This perspective is also reflected in contemporary republican work on freedom. ${ }^{66}$ It is also interesting that though Fuller rejected the Millian "negative" conception of freedom in no uncertain terms, he did not align his view with any of the ideas Isaiah Berlin identified as central to the "positive" conception of freedom. ${ }^{67}$ That too is in line with the work of contemporary republicans who have talked of republican freedom as a third "concept" of freedom. ${ }^{68}$ Fuller also rejected the quasi-quantitative approach to freedom, according to which one can measure whether one person is freer than another by the number and intensity of restraints imposed upon her. He stated that it was wrong to think that Americans are freer than Soviets in that they have "more yards of freedom to their citizens than do totalitarian regimes," i.e. simply more options available to them. The real difference lies "in the procedures by which it is determined how choice shall be allocated." ${ }^{69}$ A "realistic analysis of economic freedom would concern itself with determining how the citizen can effectively participate in the following vital decisions," like " $[\mathrm{w}]$ hat resources of society shall be drawn into production and how they be organized and allotted among the various productive enterprises? Who shall work where and at what jobs?" 70 Once again, this is a view reflected in more recent republican writings on freedom. ${ }^{71}$

Some may challenge my association of Fuller with republican thinking by pointing out that he does not talk of what is nowadays taken to be the sine qua non mark of republican freedom, the idea of nondomination. There is no denying that Fuller does not talk of nondomination, but even here matters are not clear-cut. First, even in historical republican writings (rather than their recent philosophical reconstruction), nondomination is not always the central concept, at least not explicitly. What one does find is an emphasis on the idea of self-government as a way for members of a polity to be "in charge" (and thus free) and as a mechanism for decentralizing power and thus limiting the

${ }^{66}$ See Philip Pettit, On People’s Terms: A Republican Theory and Model of Democracy 83, 9 i (20 3 ).

${ }^{67}$ In Fuller, Case Against Freedom, supra note 8, at 31 8, he goes so far as to call the distinction between negative and positive freedom "analytically untenable."

${ }^{68}$ See PetTit, supra note 62, at 17-3 I; Quentin Skinner, A Third Concept of Liberty, I I7 Proc. BriT. ACAD. 237 (2002).

${ }^{69}$ Fuller, Reflections, supra note 8 , at $73-74$.

${ }^{70} I d$. at 77 (emphasis added).

${ }^{71}$ Cf. PeTTIT, supra note 66, at 45-47. Pettit does not reject altogether the ability to measure freedom, but says "there is no reason to expect a plausible, more or less mechanical algorithm" for the measurement of freedom. Id. at 47. The place of participation in republican thought is contested. The sense Fuller endorsed seems to me to fit the weak sense found in the work of Pettit. See id. at 226-27. There is no hint in any of Fuller's writings that he believed that political participation was the key to social harmony. In fact, Fuller was clear that he did not find such harmony desirable: "It is often assumed that the existence of tensions, contradictions and competing principles of order within a society is a sign of impending dissolution and death. We assert, on the contrary, that the absence of these tensions, contradictions and competing principles is one of the surest symptoms that a society is dying." FULLER, supra note 16 , at 7 I 7 . This is the opposite of what one finds in the writings of a different strand of republicanism represented by Rousseau and more recently in the works of Michael Sandel. 
potential for its abuse. ${ }^{72}$ Fuller's notion of reciprocity may be understood as an attempt to adapt the notion of self-government to the conditions of the modern state. ${ }^{73}$ Second, I believe the contrast between law and tyranny (that I discuss in more detail in the next subsection) is directly linked to the idea of freedom as nondomination.

\section{(b) Fuller's Political Jurisprudence}

Now that Fuller's ideas on freedom are clearer, we can see how they complement his jurisprudence. The central idea is that inherent in law are certain implicit restrictions on power such that "unlimited power" is synonymous with "lawless power." J4 John Locke provides a crisp, forthright, articulation of its central idea: "Where-ever Law ends, Tyranny begins." 75 Locke further stated that

in all states of created beings capable of Laws, where there is no Law, there is no Freedom. For Liberty is, to be free from restraint and violence from others which cannot be, where there is no law: But Freedom is not, as we are told, $A$ Liberty for every Man to do what he lists: (For who could be free, when every other Man's Humour might domineer over him?) But a Liberty to dispose, and order, as he lists, his Person, Actions, Possessions, and his whole Property, within the Allowance of those Laws under which he is; and therein not to be subject to the arbitrary Will of another, but freely follow his own. ${ }^{76}$

On this view law and freedom are both contrasted with tyranny in the sense that the elimination of tyranny requires the creation of laws. As Locke has stressed "the end of Law is not to abolish or restrain, but to preserve and enlarge Freedom." 77

These ideas played a significant role during the American revolution, ${ }^{78}$ and as the quote from Hart above has shown they continued to have resonance in American life in the r950s. Against this background, the following words from Fuller's first reply to Hart appear in a new light:

$[T]$ here is nothing shocking in saying that a dictatorship which clothes itself with a tinsel of legal form can so far depart from the morality of order, from the inner morality of law itself, that it ceases to be a legal system. When a system calling itself law is predicated upon a general disregard by judges of the terms of the laws they purport to enforce, when this system habitually cures its legal irregularities, even the grossest, by retroactive statutes, when it has only to resort to forays of terror in the streets, which no one dares

\footnotetext{
${ }^{72}$ See, e.g., TOCQUEVILLE, supra note 60, at 74-77, I $10-12$.

${ }^{73}$ Cf. Pettit, supra note 62, at 67-68 (considering "reciprocal power" as a nondomination strategy).

${ }^{74}$ See Fuller, supra note 6, at 37 (quoting John Lilburn, ENGLAND’s BirTh-Right Justified (i 645)).

${ }^{75}$ John Locke, Two Treatises OF GOVERnMENT $§$ II.202 at 400 (Peter Laslett ed., I 988 ).

${ }^{76} \mathrm{Id}$. at $\$$ II. 57 at 306 .

${ }^{77} I d$.

${ }^{78}$ The literature on the place of republican ideas at the time of the American revolution is vast. On the particular point mentioned in the text see, for example, BERNARD BAILYN, THE IDEOLOGICAL ORIGINS OF THE AMERICAN REVOLUTION $76-$ 8 I (enlarged ed. I992).
} 
challenge, in order to escape even those scant restraints imposed by the pretence of legality - when all these things have become true of a dictatorship, it is not hard for me, at least, to deny to it the name of law. ${ }^{79}$

To illustrate this point consider one of Fuller's less known fables, one that tells the story of the mirrorimage of Rex, the antihero of The Morality of Law. Rex was a good-intentioned malevolent ruler; the protagonist of this story is the mean-intentioned benevolent ruler. As Fuller does not name him, I will call him Anti-Rex. Though Anti-Rex is "bent entirely on serving his own interests," ${ }^{80}$ he comes to realize that for the sake of increasing his own self-interest, he should accord his subjects some discretion. "Simply from the standpoint of engineering efficiency in achieving a goal, some discretion and choice must...be accorded the human agent." ${ }^{\text {"1 }}$ The self-interested ruler, then, realizes that to promote his own interests he should make his subjects happy, as they are more likely to serve him in such circumstances. For that end, the subject "must feel that he is serving not only the ends of another, but his own as well." ${ }^{82}$ In the last step, Anti-Rex realizes that he should allow people to improve and develop themselves for his own sake.

If this sounds like an odd tyrant, it is because this was precisely Fuller's point:

Our tyrant, you will observe, has found himself caught in a kind of progression. He started by seeking engineering efficiency, he then moved at least some way toward doing what is essential for human happiness, and he may end by fostering the conditions most conducive to human development. If he traverses fully the three steps of this progression he will, of course, finish by ceasing to be a tyrant..$^{83}$

There are certain ambiguities in the story: does Fuller mean that tyranny is irrational for the person exclusively intent on the pursuit of his own interests? Or does he mean that the reflective tyrant will come to see the wrongness of his ways? We can leave these questions unanswered, for a more pressing question is, Is Anti-Rex's move away from tyranny also inevitably a move into law? I have already quoted Fuller's claim that " $[\mathrm{t}] \mathrm{o}$ embark on the enterprise of subjecting human conduct to the governance of rules involves of necessity a commitment to the view that man is, or can become, a responsible agent, capable of understanding and following rules, and answerable for his defaults. ${ }^{" 84} \mathrm{He}$ added that the principles of legality lose their "reason for being" if humans are treated as incapable of responding to reasons. In an important sense the steps taken by Anti-Rex reflect a similar transition. Fuller describes the three steps in question as an affirmation of the idea that law "by its very nature [is] a cooperative enterprise." 85

\footnotetext{
${ }^{79}$ Lon L. Fuller, Positivism and Fidelity to Law-A Reply to Professor Hart, 7 I HARV. L. Rev. 630, 660 (1958).

${ }^{80}$ Fuller, Allocation of Choice, supra note 8, at 105.

${ }^{81} I d$. at $105-06$.

${ }^{82} \mathrm{Id}$. at 106.

${ }^{83} I d$. (emphasis added); cf. Fuller, Tyranny, supra note 8, at 1038 (suggesting that crises are times when law tends to be suspended for the sake of "drastic and often arbitrary controls," and that when such crises are common, they lead to tyranny).

${ }^{84}$ FULLER, supra note 6, at 162.

${ }^{85}$ Fuller, Allocation of Choice, supra note 8, at 106.
} 
More generally, Fuller grasped here the fact that the moral evaluation of law is not limited to what it demands, but also to the manner in which it makes its demands. ${ }^{86}$ This is something that Fuller's critics who have contended that the principles of legality are merely a matter of efficiency completely miss out. The principles of legality are part of the broader question of the legitimacy of the state, the one specific to the question of lawmaking. And it is, one could possibly say, "internal" or "special" to law, because it is moral evaluation that takes into account aspects unique to the law. "External" morality is equally applicable to the evaluation of a friend's advice as it is to evaluating the law; the principles of legality (so Fuller argued) are not.

\section{(c) Evil Regimes}

I kept for last the discussion of "evil regimes," because it builds on the argument developed in this section. In its Fullerian guise the "evil regimes" argument asserts that a putative legal system that fails to maintain the principles of legality results in something that is "not simply bad law, but not law at all." ${ }^{\prime 7}$ Like the entire "evil regime" debate, I believe this is a much less important than it is made to be. Indeed, if understood as a purely conceptual question, it is nothing more than a verbal dispute. ${ }^{88}$ To give it some sense, it needs to be understood as the conclusion of a political argument. To summarize the point of the last section, if a legal governance is understood in opposition to tyranny, then the principles of legality are to be understood as constraints on the arbitrary power that is the mark of tyranny. It is in this way that Fuller's claim that "the citizen cannot orient his conduct by law if what is called law confronts him merely with a series of sporadic and patternless exercises of state power, ${ }^{" 19}$ a claim made as part of his attempt to explain why "'public order'...which may serve to keep people off the streets and in their homes"90 is not law. Framed in this way, the argument can only be understood (and challenged) on the basis of its normative assumptions about freedom.

Fuller has supplemented this normative claim with an empirical one to the effect that a regime that maintains the principles of legality is less likely to be substantively immoral. More precisely, the empirical argument comes in two versions, weak and strong. The weak version can be presented as follows:

${ }^{86}$ Cf. PeTtIT, supra note 66, at I 30; contra Leslie Green, The Concept of Law Revisited, 94 MICH. L. REV. I687, I7 I I (1996) (book review) ("The moral value of law depends primarily on the ends to which its means are put, and that is a contingent matter"). The traces to Raz's account of authority where legitimate authority depends the rightness of its demands. There is thus an affinity between Fuller's point and a recent challenge to Raz's account on exactly this basis. See Stephen Darwall, Authority and Reasons: Exclusionary and Second-Personal, I 20 ETHICS 257, 269-70 (2010). In Joseph Raz, On Respect, Authority, and Neutrality, I 20 ETHICS 279, 30 I (2010), Raz acknowledged this was a problem with his view.

${ }^{87}$ FULLER, supra note 6, at 197.

${ }^{88}$ It is notable that other prominent non-positivists attached little significance to the question of evil regimes if understood as a conceptual question. See RONALD DWORKIN, LAW'S EMPIRE 103-04 (1986); John Finnis, On Reason and Authority in Law's Empire, 6 LAW \& PHIL. 357, 376 n.27 (1987).

${ }^{89}$ FULLER, supra note 6, at I I 0.

${ }^{90} \mathrm{Id}$. at $\mathrm{I07.}$ 
(a) Social practices have their own "natural laws" that make them possible.

(b) Law's "natural laws" are the principles of legality, because these principles make subjecting humans to the governance of rules (in the way explained above) possible.

(c) Adherence to the principles of legality in this way presupposes respect for human personhood.

(d) Respect for human personhood does not go along with support for some substantively immoral laws.

(e) Therefore, a legal system that adheres to the principles of legality is less likely to be substantively immoral, at least insofar as the immorality in question manifests itself in disrespect for personhood.

I think this argument is sound, but it may not amount to much. It boils down to, roughly, "those who respect personhood (in procedural contexts), are likely to respect personhood (in substantive contexts)." So understood there is no causal connection between caring about the principles of legality and substantive morality. Rather, the claim is that those who accept the reasons behind respecting the principles of legality and act upon them are likely to see similar reasons to treat humans with respect in the substantive laws they enact. Though this is a weak claim, it is still significant for blocking many of the criticisms leveled at Fuller's argument. It explains why those who accept the principles of legality only if, and to the extent that, they help them advance other goals are not likely to care about substantive morality. It thus serves to distinguish between two ways of being concerned with the principles of legality and their practical implications. ${ }^{91}$

The strong version of Fuller's argument is more interesting, but also much more difficult to accept without supporting empirical evidence. It suggests some causal link between maintaining the principles of legality and substantive morality. Some years before The Morality of Law Fuller wrote that the "[p]ower [to make and enforce rules] is ineffective as a principle of social organization unless it is legitimated, that is, unless it is accepted as right and proper by at least a substantial portion of those subject to it." ${ }^{\prime 2}$ The reason is that "[n]o social organization above the level of an alley gang was ever organized about the capacity to inflict physical harm....[N]o society has ever been organized through descending echelons of physical fear." ${ }^{\text {"93 }}$ Indeed, to the limited extent that sheer force exists, three things obtain: based on sheer power it is parasitic on an organization not itself based on physical fear, the efficiency of such organization is low, and over time "some obscure conception of fairness and right dealing" tends to emerge. ${ }^{94}$

Fuller asserts here that beyond the most basic uses of force, power requires legitimation to maintain itself, and that as a matter of fact it tends to generate processes that legitimate it. The

\footnotetext{
${ }^{91} \mathrm{I}$ believe this is an effective response to arguments directed at Fuller such as in MATTHEW H. KRAMER, IN DEFENSE OF Legal Positivism: LaW Without Trimmings 62-7i (1999).

${ }^{2}$ FULLER, supra note 16, at 701-02. The idea of the special legitimacy of the process of law, as distinct from the legitimacy of what it demands - the idea represented in (7) - is not yet found in this early work.

${ }^{93} \mathrm{Id}$. at $702-03$.

${ }^{94}$ See id. at 703. This is, of course, the point of the story of Anti-Rex.
} 
principles of legality can thus be understood as the road to legitimation. Against this background, the strong version of Fuller's empirical argument is that a regime that starts with concern for the principles of legality only out of self-interest (i.e., only to the extent that it serves its goals) may over time drift towards respecting personhood, both procedurally and substantively. ${ }^{95}$ The causal link may thus be established either directly, if we show that the purely instrumental pursuit of the principles of legality tends to transform into a freedom-based protection of legality; or it can be established indirectly if it can be shown that the instrumental adoption of the principles of legality may give a regime certain stability that will (tend to) start the slow process of legitimation.

This is a very optimistic story, and undoubtedly it can be countered by a pessimistic one: Realizing that people tend to associate respect for procedural legality with legitimacy, ${ }^{96}$ the evil ruler may come to exploit respect for procedural morality for the pursuit of self-interested (or worse) ends. Strict compliance with procedural morality may lure the law's subjects to mistake it for respect for substantive justice. This is different from the claim that the principles of legality are simply an efficient way of getting one's way, but it is no less, perhaps more, sinister in its implications.

It is difficult to be sure which story is more likely to be realized, especially since both stories can be true in different times and places. Part of the difficulty in evaluating these stories has to do with the difficulty of operationalizing the relevant variables and measuring them; but part of the difficulty, no less significant, is that assessing this claim requires making evaluative judgments on the substantive morality of different regimes. Those who think that Western democracies are, by and large, just (or at least not grossly unjust), may well be sympathetic to the idea (or at least the possibility) of "civilizing" effects of procedural constraints on substantive law. Those more critical of such states as unjust and hypocritical may find the principles of legality nothing but a cynical ploy to trick individuals into a false sense of complacency and unjustified trust in unjust regimes. Obviously, these are questions that cannot be answered here. But if I am correct, I have shown a way of understanding Fuller's empirical claim as one worthy of serious examination.

\section{Implications for Contemporary Debates}

Why has all this been ignored? No doubt, Fuller deserves part of the blame. He did not draw clear links between his work on freedom and his work in jurisprudence. But even if he has not done that,

${ }^{95}$ Further evidence that this was indeed how Fuller understood his claim is provided by a letter exchange Fuller had shortly after the publication of The Morality of Law. Fuller was challenged that antebellum America had law and slavery at the same time. In response Fuller wrote: "That laws protected the master's property right in his slave is, of course, true. It is also true that laws gradually gave the slave many rights, including that of protection against abuse, or buying his own freedom, etc...." Letter from Fuller to Walter F. Berns, Oct. 14, 1964, located in The Papers of Lon L. Fuller, Harvard Law School Library, Box I I, Folder I 7, quoted in RUNDLE, supra note I 2, at I I 3.

${ }^{96}$ Perhaps based on empirical evidence such as found in Tom R. Tyler, Procedural Justice, Legitimacy, and the Effective Rule of Law, 30 CRIME \& JUST. 283 (2003). 
why haven't others? In part, it may have to do with the fact that republican conception of freedom was until fairly recently somewhat overshadowed by Berlin's contrast between negative and positive freedom, into which, as already noted, republican freedom fits rather poorly. Even after the "republican revival" it may be that Fuller's original blending of republican ideas with ideas coming from distinctly un-republican sources may have obscured understanding of his thought. ${ }^{97} \mathrm{I}$ think, however, that an important, perhaps the main, reason for the neglect of Fuller's ideas on freedom, has to do with the contemporary tendency to separate jurisprudence from political theory. As a result, Fuller's writings on freedom could have been ignored exactly because their overt concern with political concepts seemed to imply they could have no bearing on legal theory. These writings' reference to freedom in their title was all that a legal philosopher needed to conclude that they can be safely ignored. For this reason I wish to address here, quite briefly, some of the broader questions of jurisprudence, in particular its point. I will try to show that some things Fuller has said on the matter already in the 1960 s remain significant fifty years on.

\section{(a) The American Jurisprudence of Lon Fuller}

I opened this essay with the question whether it made sense to talk about American jurisprudence. Based on what I have written above, I would like now to explain why it may be so, at least as far as Fuller's jurisprudence is concerned. One sense, psychological or biographical, is that Fuller (just like Hart, Dworkin, Kelsen, ${ }^{98}$ or anyone else) wrote against the background of a legal system and a political tradition he was familiar with, and so he may have come to see the familiar as natural or even inevitable. Fuller may have relied on broadly republican ideas of freedom, because they had played a more significant role in American political history than in that of other countries, and being immersed in American political discourse he may have come to see them as the "correct" ones.

Presented as such, against the background that sees the aim of jurisprudence to provide a universal account of the nature of law, this may seem like a failure on Fuller's part, reflecting his inability to extract himself sufficiently from the particular political history of his own country. I suggest a different way of understanding Fuller's argument. My claim is not that Fuller's jurisprudence is "American" because Fuller was American. After all, that these ideas have found prominence in the American political thought and American political institutions, does not imply that one has to be an American to write jurisprudence inspired by these political idea(l)s, even less so that only an American could notice or grasp them. In this respect, these ideas are universal.

Fuller's jurisprudence can nevertheless be seen as "American" in the sense that it sought a theory of law grounded in ideas that proved prominent in American politics, and arguably have played a

${ }^{97}$ This may be why Fuller was wrongly associated with libertarianism. See note i 6, supra.

${ }^{98}$ See Dan Priel, Is There One Right Answer to the Question of the Nature of Law?, in PHILOSOPHICAL Foundations OF THE NATURE OF LAW 322, 338-40 (Wil Waluchow \& Stefan Sciaraffa eds., 2013) (discussing the localisms in Hart, Dworkin, and Kelsen). 
significant role in the shaping of American political and legal institutions. ${ }^{99}$ Fuller was impressed by Michael Oakeshott's treatment of the idea of a political tradition, and in particular with Oakeshott's claim that the study of politics and political institutions is the study of the "intimations' of our traditions." ${ }^{100}$ Put simply, what matters is not that Fuller was influenced by republican ideas of freedom, but that American lawyers were.

\section{(b) Is Conceptual Jurisprudence Possible?}

Those who dislike Fuller's work for all its supposed confusions might welcome my reconstruction of his ideas as proof that he committed the ultimate jurisprudential sin: he confused politically-neutral conceptual jurisprudence with normative political theory. ${ }^{101}$ More charitably, they might admit that Fuller may not have been the fool they had taken him to be, that he concerned himself with valid and valuable questions, but ones that are decidedly different from theirs. The question they are concerned with, and the only question that belongs to general jurisprudence properly and strictly so-called, is precisely the part that remains of law after we have removed from it all local influences, including political ones.

This, however, is not how Fuller saw things. Fuller did not think he was merely engaged in a different enterprise, leaving the conceptual inquiry for those more interested in it. Fuller clearly doubted the possibility of the conceptual enterprise. He made it clear in The Morality of Law that he thought conceptual jurisprudence was "without intelligible content," and which has led legal theorists to a "blind alley." 102 Shortly afterwards he wrote: "standing like a huge question mark over the whole analytical school is W.V. Quine's unrefuted and still imperfectly absorbed challenge to the distinction between analytic and synthetic judgments...." ${ }^{103}$ Two years later, he ended his "Reply to Critics" with

${ }^{99}$ Almost alone in recognizing this fact (albeit briefly) is RiChard A. Posner, THE PROBLEMS OF JuRISPRUdenCE 230 (1 990) (characterizing the debate between Hart and Fuller as "as much cultural as intellectual"). Posner, however, relates the difference to the fact that the U.S. has a judicially enforceable constitution whereas England does not. See id. Apart from that I know of only one extended attempt to place Fuller's work within its "cultural” context. See John W.F. Allison, Legal Culture in Fuller's Analysis of Adjudication, in REDISCOVERING FULLER: ESSAYS ON IMPLICIT LAW AND INSTITUTIONAL DESIGN 346 (Willem J. Witteveen \& Wibren van der Burg eds., I 999). But Allison's essay focuses on the contrast between the "AngloAmerican" (adversarial) and the "Continental" (inquisitorial) models of adjudication, whereas one of my aims in this essay is to separate the Anglo from the American on the basis of their distinct political traditions.

${ }^{100}$ Letter from Lon L. Fuller to H.L.A. Hart (Oct. 19, 1959) (quoting Michael Oakeshott, Political Education, in RATIONALISM IN POLITICS AND OTHER ESSAYS 43, 58 (expanded ed. I 99i)), quoted in Lacey, supra note I6, at I 5.

${ }^{101}$ Cf. Hart, Positivism, supra note 4, at 6 I 8.

${ }^{102}$ FULLER, supra note 6, at i 10.

103 LON L. Fuller, Legal Fictions, at xii (1967). Fuller thus anticipated Leiter's Quine-inspired challenge to conceptual jurisprudence, see LEITER, supra note I, at 2-3, I 3 I-35, by some three decades. (I thank Chris Boom for alerting me to this passage.) 
the exasperated plea that "legal philosophers...cease to be preoccupied with building 'conceptual models' to represent legal phenomena." 104

For Fuller, if the question "what is law?" is to be given a "philosophical" answer (as opposed to a detailed empirical account), it necessarily involves the invocation of an ideal-type. In "actual life" law and managerial direction (and presumably all other forms of social order) "present themselves...in many mixed, ambiguous, and distorted forms." 105 The contribution a philosopher can make to understanding a social practice was not by attempting to identify the features that are unique to the practice as it is; rather, the philosopher can illuminate the practice by presenting a pure case which may have never existed. It is exactly this fact that can explain why and how it can illuminate the practice. To be sure, an ideal-type had better bear some resemblance to the real-world practice we call "law," for otherwise it would not be particularly useful for understanding (and improving) that practice; in this respect Fuller's account is obviously based on certain assumptions on what law is actually like. These assumptions are observational and in this respect such an account may be challenged on "descriptive" grounds. But beyond that, an ideal-type is not a description. It is a reconstruction, based on normative standards. I believe this is a running theme in Fuller's thinking from long before his exchanges with Hart, and can be traced back to his repeated insistence on the impossibility of clearly separating "is" and "ought," which may be understood as a somewhat clumsy way of rejecting the distinction between conceptual and normative jurisprudence. ${ }^{106}$

If this is true, it must be the case that even those who believed they were engaged in pure conceptual jurisprudence were in fact doing something else, that just like him their conceptual analysis depended on political ideas, only he was more aware what he was doing. In his writings on freedom Hart was clearly sympathetic to a more "negative" conception of freedom, freedom as noninterference, ${ }^{107}$ and as his words comparing the English and the American understandings of freedom indicate, he took the negative conception to represent the prevailing view of freedom in England. One way of understanding Fuller's challenge is that Hart's "conceptual" claims about law owe more than he realized to this conception of freedom. ${ }^{108}$ Hart saw law primarily as a means to guide conduct, ${ }^{109}$ and he saw it primarily a set of rules imposed from above. As he put it, unlike the pre-legal society, in the

${ }^{104}$ FULLER, supra note 6, at 242.

${ }^{105} \mathrm{Id}$. at 208. Fuller explicitly talks there of "ideal types" of law and managerial discretion. Id. Incidentally, in his more recent writings on jurisprudence Raz has said the same thing. See RAZ, supra note 32, at I03 ("To understand the nature of law is to understand, among other things, the ideal which the law should live up to, and also to understand that it can fail to live up to that ideal").

106 This is a central theme in LON L. FULLER, THE LAW IN QUEST OF ITSELF (1 940); see also Fuller, supra note i 4, at 697-99.

107 See H.L.A. Hart, Rawls on Liberty and Its Priority, 40 U. CHI. L. REV. 534, 54 I ( 973 ); Hart, supra note 60, at 89; see generally H.L.A. HART, LAW, LIBERTY AND MORALITY (1963).

108 Contra Green, supra note $3 \mathrm{I}$, at lii (arguing that Hart's jurisprudence had nothing to do with his "Millian liberalism").

${ }^{109}$ See HART, CONCEPT, supra note 4, at I oo, I 35, 249. 
legal system "the acceptance of the rules as common standards for the group may be split off from the relatively passive matter of the ordinary individual acquiescing in the rules by obeying them for his part alone." ${ }^{110}$ From this perspective, it is not surprising that the principles of legality are perceived as merely technical guarantees for the efficient delivery of edicts from ruler to subject. But this conclusion depends on an implicit acceptance of the Hartian picture of law, which in turn is based on a particular view of freedom.

This point is of much greater significance for debates about the nature of law than my comparison of the works of Hart and Fuller. ${ }^{111}$ After all, the committed conceptualist could accept that Hart's theory was less conceptually "pure" than he thought it to be and then call on legal philosophers to double down on their efforts to purge jurisprudence of infiltrations from political philosophy. This response raises many questions that go beyond the scope of this essay and which I cannot address here. For the record I will assert without much argument that the view that any attempt to answer the question of the nature of law in a particular jurisdiction must presuppose an answer to the question to

${ }^{110} I d$. at I 17 . I would have thought the view that Hart offered a top-down theory of law uncontroversial, but recently this view has been challenged. See Jeremy Waldron, Legal Pluralism and the Contrast Between Hart's Jurisprudence and Fuller's, in HART-Fuller Debate, supra note i 6, at I 35, 1 39-4 I; Leslie Green, Law as a Means, in HART-Fuller Debate, supra note I 4, at I 69, I 88. Contrary to Green's claim, Hart did not give much significance for "the facilities [law] provides for private individuals to arrange their affairs." Id. It is true that Hart mentions this idea, see HART, CONCEPT, supra note 4, at 27-28, but it is worth noting that Hart also considered contract, the main means by which people may be involving in creating law from the bottom-up, a "relatively minor legal institution[].” H.L.A. HART, PUNISHMENT AND RESPONSIBILITY: ESSAYS IN THE PHILOSOPHY OF LAW io (2d ed. 2008). Beyond this, all other "facilitative" rules Hart talked about do not give people an active role in making the law. Just like the rest of the law in Hart's picture, these rules are set from above. It is also not true that Hart thought there was a need for the "voluntary co-operation of large number of people without which law could not exist at all." Green, supra, at i 88. On the contrary, Hart insisted that law could exist even in a society where "only officials...accept[ed] and use[d] the [legal] system's criteria of legal validity" and for all others law was mere threats backed sanctions. Such a society "might be deplorably sheeplike..., [b]ut there is little reason for thinking that it could not exist or for denying it the title of a legal system." HART, CONCEPT, supra note 4, at I 17 . Waldron is more receptive to the claim that of Hart's offered a top-down account, but qualifies it in two ways. Hart rejected the command theory and replaced it with an account of a group of officials accepting a shared social rule, and he accepted custom as a source of law. I do not see how the first point in any way changes the top-down structure of Hart's account when it is officials' acceptance of the rule of recognition that matters. The second, the role he gave for custom, is more significant, although even here, as Waldron himself notes, Hart's concession was minor as "[c]ustom in the modern world is not a very important 'source' of law." HART, CONCEPT, supra note 4, at 45. The contrast with Fuller is striking. See, e.g., Fuller, supra note I I, at 3 ("we cannot understand 'ordinary' law...unless we first obtain an understanding of...customary law"), 24 ("the existence of enacted law as an effectively functioning system depends upon the establishment of stable interactional expectancies between lawgiver and subject"); Fuller, supra note 61, at 94 ("we have to say of customary law not simply that it serves to facilitate interaction, but that it derives tacitly from interaction. This makes it a subject difficult to reconcile with the usual presuppositions underlying general theories of law").

${ }^{111}$ Elsewhere I have given other examples of supposedly purely conceptual jurisprudence that is in fact based on politics. See Priel, supra note 98; Dan Priel, Are Jurisprudential Debates Conceptual? Some Evidence from Democratic Theory, 50 OSGOODE HALl L.J. 359 (2012). 
the more abstract question of the nature of law in general ("If there is no general jurisprudence...then there is also no special jurisprudence"112) is false. This view presupposes that all things we call "law" belong to the same kind, but that is an unwarranted and question-begging assumption. Even if I am wrong about that, it is worth pointing out that those who propose this view must openly acknowledge that there may be nothing (or at least nothing illuminating) left after we have stripped a philosophical account of what law is of its political elements.

There is one challenge I will address here because it concerns my argument. The challenge is that my argument would seem to imply that the English don't have law, or that what they call law is a different form of social order from American law. Fuller did not explicitly endorse anything like this view, indeed his attempt to explain what law is, even if based on political premises, suggests he would have rejected this view. There are several possible responses to this view. One is that Fuller would have argued that even English law is committed to the protection of the procedural principles of legality and that is sufficient to show that English law belongs to the same form of social order. Another might be to argue that notions of reciprocity are also present in English law, perhaps by developing the familiar idea that the common law as a form of customary law. Yet another might be to argue that to the extent that English law is no longer reciprocal in the manner he discussed, its legitimacy is threatened. ${ }^{113}$ Finally, Fuller may bite the bullet and concede that American and English law do indeed reflect different forms of social order, each with its mode of legitimation.

\section{Conclusion}

Since so much of what is currently debated in contemporary English-language jurisprudence can be traced back to the exchange that Hart's Concept of Law and Fuller's Morality of Law were part of, it is difficult to avoid comparisons between the two books. Elsewhere I have expressed the view (undoubtedly crazy, in the eyes of many) that for all its flaws, Fuller's book is the more insightful of the two. ${ }^{114}$ It is also the more frustrating one. Over the years numerous people have mentioned some (valid) reasons for this frustration. This essay shows that the insight and frustration derive from the same source. As I tried to show Fuller's writings are full of interesting ideas, often drawing links between seemingly unrelated issues. Unfortunately, the same features tend to throw Fuller off in different directions in a fashion that can seem confused and confusing. A more careful dissection of

112 GARDNER, supra note $3 \mathrm{I}$, at 279.

${ }^{113}$ Fuller made interesting comments indirectly related to the last two points made in the text. In Fuller, supra note I $\mathrm{I}$ at 26, Fuller challenges the view that the common law is "simply a form of enacted law," and which ignores its "special qualities" which make it akin to customary law, and which as such "projects its roots more deeply and intimately into human interaction than does statutory law." Interestingly, Fuller says that the common law's "country of...origin" the common law is losing these qualities "perhaps because its judges have finally begun to conform their practice to the pattern legal theory has been ascribing to it for more than a century." Id.

${ }^{114}$ See Priel, supra note 30, at 399-400. 
Fuller's ideas of freedom than I could do here might have attempted to disentangle interaction from participation and reciprocity from self-government in a more discrimination fashion. It might have inquired more carefully into the relationship of all these ideas to freedom (as nondomination). That is not where Fuller's strengths lay. But what his work shows is that there is more to the understanding of human affairs than analytic rigor.

This essay has added yet another reason for finding The Morality of Law frustrating. It is frustrating, because if I am right, one cannot make sense of what's in the book without taking into account of ideas developed elsewhere and which are only alluded to in it. As those ideas have largely been ignored, it is perhaps no surprise that the book has often been misunderstood. Properly understood the book should be read not just as a critique of legal positivism, but more fundamentally as a critique of the divide between conceptual and normative jurisprudence that twentieth-century legal positivism presupposes. On the positive side, The Morality of Law together with Fuller's ideas on freedom can be understood as providing the foundations for understanding law in the modern state. It is well-known that one of the marks of modern state is the massive expansion of the scope and reach of law to all aspects of human life. Understandably, this has been a cause for much concern about the way modern law is nothing but a mask for an all-consuming tyranny. The most neglected message of The Morality of Law may be Fuller's attempt to explain how, despite this enormous expansion, law may remain legitimate. 